\title{
Protective effect of geranylgeranylacetone on trinitrobenzene sulfonic acid-induced colitis in mice
}

\author{
TATSUYA OHKAWARA ${ }^{1,2}$, JUN NISHIHIRA ${ }^{2}$, HIROSHI TAKEDA ${ }^{1}$, TAKEHIKO KATSURADA ${ }^{1}$, \\ KANJI KATO $^{1}$, TAKASHI YOSHIKI ${ }^{2}$, TOSHIRO SUGIYAMA ${ }^{3}$ and MASAHIRO ASAKA ${ }^{1}$ \\ ${ }^{1}$ Department of Gastroenterology and Hematology, Hokkaido University Graduate School of Medicine; \\ ${ }^{2}$ Department of Research and Development, Genetic Lab. Co., Ltd., Sapporo; ${ }^{3}$ Third Department of \\ Internal Medicine, Toyama Medical and Pharmaceutical University, Toyama, Japan
}

Received October 3, 2005; Accepted November 14, 2005

\begin{abstract}
Geranylgeranylacetone (GGA) has recently been reported to have a protective effect against ischemic, injurious and apoptotic stress in several tissues. The aim of this study was to determine the effect of GGA on colitis induced by 2,4,6trinitrobenzene sulfonic acid (TNBS) in mice. Colitis was induced by intrarectal instillation of TNBS in $50 \%$ ethanol in $\mathrm{BALB} / \mathrm{c}$ mice. Survival, change in body weight and change in wet colon weight were assessed. Histological score in the colon was evaluated 5 days after TNBS treatment. The level of myeloperoxidase (MPO) activity in the colon was also determined. Immunohistochemistry for CD4 in the colon was performed. In addition, the level of heat shock protein (HSP) 70 in the colon was determined by Western blot analysis. Mice were orally treated with GGA $(300 \mathrm{mg} / \mathrm{kg}) 2 \mathrm{~h}$ before and every other day after starting TNBS administration. Treatment with GGA markedly improved the survival rate, and reduced the loss of body weight and loss of wet colon weight in mice with TNBS-induced colitis. GGA also suppressed the increase in MPO activity and the number of CD4-positive cells infiltrating the colons of mice with TNBSinduced colitis. Furthermore, treatment with GGA remarkably up-regulated the expression of HSP70 in the colons of mice with TNBS-induced colitis. Our results provide further evidence that GGA has therapeutic potential for intestinal inflammation.
\end{abstract}

Correspondence to: Dr Tatsuya Ohkawara, Department of Gastroenterology and Hematology, Hokkaido University Graduate School of Medicine, N15, W7, Kita-ku, Sapporo 060-8638, Japan

E-mail: tokawara@med.hokudai.ac.jp

Abbreviations: HSP, heat shock protein; GGA, geranylgeranylacetone; TNBS, trinitrobenzene sulfonic acid; MPO, myeloperoxidase; IBD, inflammatory bowel disease

Key words: colitis, geranylgeranylacetone, heat shock protein, inflammatory bowel disease, trinitrobenzene sulfonic acid

\section{Introduction}

Ulcerative colitis and Crohn's disease are the major inflammatory bowel diseases (IBDs) in humans and are characterized by chronic relapsing intestinal inflammation. Although numerous studies on IBD have been carried out, the etiology of IBD still remains unknown (1). Recent studies have demonstrated that various inflammatory mediators, including tumor necrosis factor (TNF)- $\alpha$ and macrophage migration inhibitory factor (MIF) are involved in the pathogenesis and exacerbation of IBD (2-4).

5-Aminosalicylic acid (ASA), glucocorticoids, and immunosuppressive and immunoregulatory agents are commonly used for the treatment of IBD (1). Unfortunately, some IBD patients are unresponsiveness to treatment with these agents. Recently, infliximab, an anti-TNF- $\alpha$ monoclonal antibody, has been used for the treatment of Crohn's disease $(5,6)$. However, side effects, such as infection and malignancy, have been reported in some IBD patients $(7,8)$.

Geranylgeranylacetone (GGA) is an acyclic polyisoprenoid that can protect the stomach from mucosal injury such as ulceration. This compound is effective for protecting the gastric mucosa from various stresses $(9,10)$. In addition, GGA increases synthesis and secretion of gastric mucin (11) as well as components of high-molecular-weight glycoproteins and surface-active phospholipids (12). Interestingly, it has been reported that GGA enhances the expression of heat shock protein (HSP) in gastric mucosal cells and in several tissues and that it protects cells and tissues from destruction and inflammation (13-16). HSP is considered to be a stressinducible protein that exhibits protective properties and regulates the immune response (17). HSP plays a pivotal role in operating as an intracellular chaperone for aberrantly folded or mutated proteins, and it provides a protective function to cells under stressful conditions (17). HSP70, named after its molecular weight of approximately $70 \mathrm{kDa}$, has a strong cytoprotective function against stress in the stomach, liver and heart (18-20). Transgenic overexpression of HSP70 also protects the mouse heart against tissue injury $(21,22)$. In the human bowel, the expression of HSP70 is enhanced in ulcerative colitis compared to non-specific colitis in the colonic mucosa (23). Another study has shown that HSP70 induced 
by heat stress contributes to the suppression of acetic acidinduced colitis in rats (24). However, the role of HSP70 in colitis has not been fully elucidated. Therefore, the aim of this study was to investigate the effect of GGA on experimental colitis induced by 2,4,6-trinitrobenzene sulfonic acid (TNBS) in mice and to determine whether GGA enhances the expression of HSP70 in mice with TNBS-induced colitis as well as in other experimental models.

\section{Materials and methods}

Animals and study protocol. Specific pathogen-free 8-weekold BALB/c male mice weighing 22-25 g were obtained from Japan Charles River Co. (Shizuoka, Japan). Mice were comfortably housed under standard conditions of temperature, humidity and light/dark cycle. Mice could access food and water ad libitum. All experimental protocols adhered to the Declaration of Helsinki and were approved by the Animal Experiment Ethics Committee of the Graduate School of Medicine of Hokkaido University.

Mice were starved for $12 \mathrm{~h}$ and colitis was induced in mice by intrarectal administration of $0.5 \mathrm{mg}$ of TNBS (Sigma, St. Louis, MO) in $0.1 \mathrm{ml}$ of $50 \%$ ethanol using a nylon catheter as previously described (25). The mice were weighed and visually inspected every day beginning on day 0 . The percent weight change for each individual mouse compared to the weight on day 0 was calculated. On the 5 th day after TNBS administration, the mice were euthanised by intraperitoneal injection of thiopental and the colon tissue was removed. The wet colon weight was immediately measured. For assessment of histology, colon tissue was longitudinally opened, fixed with $10 \%$ neutral buffered formalin, and embedded in paraffin. For analyses of myeloperoxidase (MPO) activity and HSP70, colon tissues were stored at $-80^{\circ} \mathrm{C}$ until use. For determination of the survival rate, each mouse was intrarectally administered $1 \mathrm{mg}$ of TNBS in $0.1 \mathrm{ml}$ of $50 \%$ ethanol.

Histologcal evaluation. After deparaffinization of thin tissue sections on glass slides, the colon tissue was stained with hematoxylin and eosin (H\&E). Histological evaluation was microscopically evaluated and quantitated by an expert pathologist using the method described previously (25). Briefly, the degree of inflammation was graded from 0 to 4 as follows: 0 , no leukocyte infiltration; 1 , low level of leukocyte infiltration; 2, moderate level of leukocyte infiltration; 3, high level of leukocytic infiltration, high vascular density, and thickening of the colon wall; 4, transmural leukocyte infiltration, loss of goblet cells, high vascular density, and thickening of the colon wall. All slides were blinded for scoring.

GGA treatment. GGA was provided by Eisai Co. (Tokyo, Japan), as an emulsion with $5 \%$ gum arabic and $0.0008 \%$ $\alpha$-tocopherol. GGA was given to mice orally in a volume of $5 \mathrm{ml} / \mathrm{kg} /$ time at a dose of $300 \mathrm{mg} / \mathrm{kg} /$ time through metal tubing attached to a 1-ml syringe. Mice in the control group were given the same dose of vehicle. Mice in each group were given GGA or vehicle $2 \mathrm{~h}$ before and every other day after starting administration of TNBS.

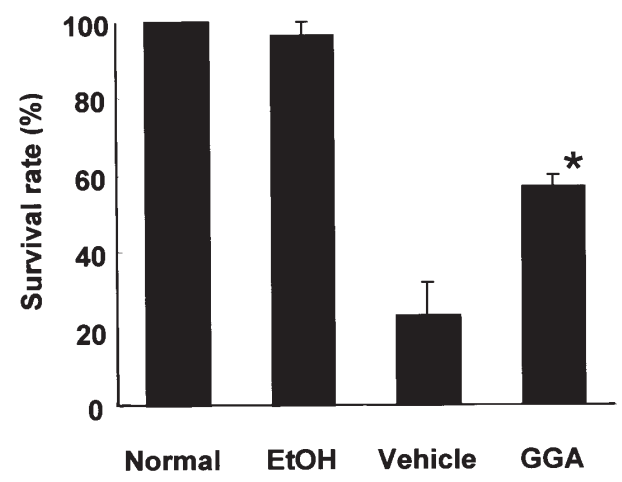

Figure 1. Effect of GGA on survival rate of mice with severe TNBS-induced colitis. Colitis was induced by intrarectal instillation of $1 \mathrm{mg}$ of TNBS with $0.1 \mathrm{ml}$ of $50 \%$ ethanol. Mice were repeatedly treated with $300 \mathrm{mg} / \mathrm{kg}$ of GGA every other day up to day 5 . Values are expressed as mean \pm standard error (SE). Three separate experiments were performed ( $n=10 /$ time). ${ }^{*} \mathrm{P}<0.01$ vs. vehicle-treated mice.

Measurement of myeloperoxidase activity. The level of myeloperoxidase (MPO) activity was determined in the colon as described previously $(27,28)$. Briefly, a tissue specimen $(\sim 300 \mathrm{mg})$ was homogenized in $50 \mathrm{mM}$ potassium phosphate buffer ( $\mathrm{pH} 6.0$ ) with $0.5 \%$ hexadecyltrimethylammonium bromide using a Polytron-type homogenizer for $3 \times 30 \mathrm{sec}$ on ice. The sample was centrifuged at $20,000 \mathrm{x}$ g for $20 \mathrm{~min}$ at $4^{\circ} \mathrm{C}$, and the supernatant was collected. Each sample $(100 \mu \mathrm{l})$ was added to $2.9 \mathrm{ml}$ of $50 \mathrm{mM}$ phosphate buffer ( $\mathrm{pH} 6.0$ ) containing $0.167 \mathrm{mg} / \mathrm{ml} \mathrm{O}$-dianisidine hydrocholoride and $0.0005 \%$ hydrogen peroxide, and the MPO activity in the sample was measured using a spectrometer at $25^{\circ} \mathrm{C}$. The protein concentration of the supernatant was determined using a Bradford assay kit (Bio-Rad Laboratories, Hercules, CA) for calibration, and values were standardized using MPO purified from human leukocytes (Sigma). Absorbance at $460 \mathrm{~nm}$ was determined for three separate 30-sec intervals. One unit of MPO activity was defined as $1 \mu \mathrm{mol} \mathrm{H}_{2} \mathrm{O}_{2}$ broken down to $\mathrm{H}_{2} \mathrm{O}$ and $\mathrm{O}-$ by MPO. The final value of MPO activity was represented as units per gram of tissue.

Immunohistochemistry. Immunohistochemical analysis for CD4 was performed with a Vectastain ABC kit according to the manufacturer's protocol. A frozen sample of colon tissue was cut to a 5- $\mu \mathrm{m}$-thick section. The section was pretreated with $3 \% \mathrm{H}_{2} \mathrm{O}_{2}$ for $10 \mathrm{~min}$ at $4^{\circ} \mathrm{C}$ and then treated with $10 \%$ normal goat serum for $30 \mathrm{~min}$ at room temperature followed by overnight incubation with an anti-CD4 antibody (diluted 1:50, BD Bioscience, San Jose, CA, USA) at $4^{\circ} \mathrm{C}$. CD4positive staining was visualized with diaminobenzidine as a chromogen. The numbers of CD4-positive staining cells in the colon mucosa were counted microscopically in a blind fashion.

Western blot analysis for HSP in colon tissue. Colon tissue was disrupted using a Polytron homogenizer (Kinematica, Lucerne, Switzerland). The homogenate was dissolved in $20 \mu \mathrm{l}$ of Tris- $\mathrm{HCl}, 50 \mathrm{mM}$ (pH 6.8), containing 2-mercaptoethanol $(1 \%)$, SDS (2\%), glycerol $(20 \%)$ and bromophenol blue $(0.04 \%)$, and heated at $100^{\circ} \mathrm{C}$ for $5 \mathrm{~min}$. The sample was then subjected to SDS-polyacrylamide gel electrophoresis (SDS- 


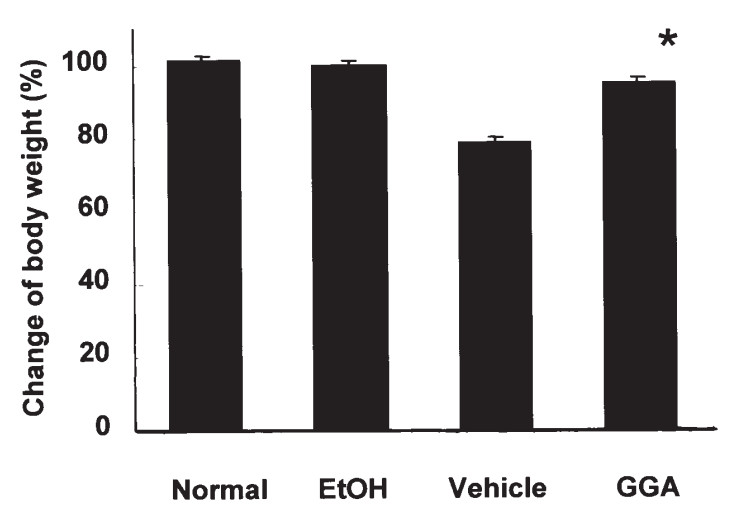

Figure 2. Effect of geranylgeranylacetone (GGA) on body weight in mice with TNBS-induced colitis. Colitis was induced by intrarectal instillation of $0.5 \mathrm{mg}$ of TNBS with $0.1 \mathrm{ml}$ of $50 \%$ ethanol. Mice were treated with $300 \mathrm{mg} / \mathrm{kg}$ of GGA every day up to day 5. Normal, non-treated mice; EtOH, ethanol-treated mice; vehicle, vehicle-treated mice with TNBS colitis; GGA, $300 \mathrm{mg} / \mathrm{kg}$ of GGA-treated mice with TNBS-induced colitis. Values are expressed as mean \pm SE. $n=5 ;{ }^{*} \mathrm{P}<0.01$ vs. vehicle-treated mice.

PAGE) and transferred electrophoretically onto a nitrocellulose membrane. The membrane was blocked with $1 \%$ non-fat dry milk in phosphate-buffered saline (PBS), probed with an anti-HSP70 antibody (diluted 1:1000, Stressgen, Victoria, Canada) and $B$-actin (Sigma), and then reacted with a goat anti-rabbit IgG antibody coupled with horseradish peroxidase (HRP). The resultant complexes were processed for the detection system according to the manufacturer's protocol. The protein concentration of the cell homogenate was quantified using a Micro BCA protein assay reagent kit.

Statistical analysis. All results were expressed as means \pm standard error (SE) and statistically analyzed using Student's t-test (StatView, SAS Institute, Cary, NC). $\mathrm{P}<0.05$ was considered as significant difference.

\section{Results}

Effects of GGA on survival, body weight and wet colon weight in mice with TNBS-induced colitis. In this model, a high dose of TNBS leads to death within 5 days. In mice treated with ethanol alone, the survival rate slightly decreased to $96.7 \pm 3.3 \%$ in comparison with non-treated controls (Fig. 1). The survival rate was remarkably decreased to $23.3 \pm 8.8 \%$ in mice given $1 \mathrm{mg}$ of TNBS. On the other hand, the survival rate was greatly improved in mice treated with $300 \mathrm{mg} / \mathrm{kg}$ of GGA $(56.7 \pm 3.3 \%, \mathrm{P}<0.01$, vs. vehicle-treated mice). The percent change in body weight was markedly decreased to $77.9 \pm 1.7 \%$ in vehicle-treated mice 5 days after initial TNBS administration in comparison with that on day 0 (100\%) (Fig. 2). In contrast, the percent loss in body weight was significantly smaller in mice treated with $300 \mathrm{mg} / \mathrm{kg}$ of GGA than in vehicle-treated mice $(94.4 \pm 1.3 \% ; \mathrm{P}<0.01$ vs. vehicle-treated mice) (Fig. 2). Wet colon weight correlates with the severity of TNBS colitis and is used as a parameter of colitis (23). Vehicle-treated mice given TNBS showed an increase in wet colon weight compared with non- or ethanol alone-treated mice $(0.63 \pm 0.04,0.42 \pm 0.07$ and $0.44 \pm 0.02 \mathrm{~g}$, respectively, $\mathrm{P}<0.01$ vs. non- or ethanoltreated mice) (Fig. 3). On the other hand, treatment with

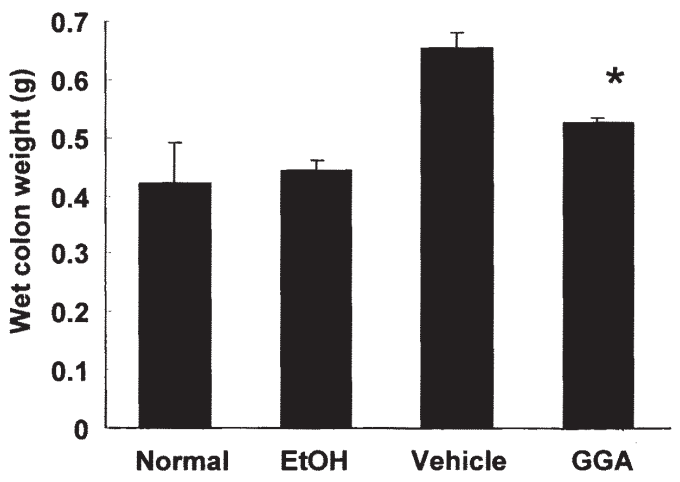

Figure 3. Effect of GGA on wet colon weight of mice with TNBS-induced colitis. Colitis was induced by intrarectal instillation of $0.5 \mathrm{mg}$ of TNBS with $0.1 \mathrm{ml}$ of $50 \%$ ethanol. Mice were repeatedly treated with $300 \mathrm{mg} / \mathrm{kg}$ of GGA every other day up to day 5 . Values are expressed as mean \pm SE. $n=5$; ${ }^{*} \mathrm{P}<0.05$ vs. vehicle-treated cells.

$300 \mathrm{mg} / \mathrm{kg}$ of GGA for 5 days significantly suppressed the increase in wet colon weight of mice with TNBS-induced colitis compared with treatment with the vehicle $(0.51 \pm 0.01 \mathrm{~g}$, $\mathrm{P}<0.05$ ) (Fig. 3).

Effects of GGA on histological findings in the colons of mice with TNBS-induced colitis. Colon tissue from mice with TNBS-induced colitis was histologically evaluated using $\mathrm{H} \& \mathrm{E}$ staining. In non-treated mice and ethanol-treated mice, there were no findings of colitis (histological scores: $0 \pm 0$ and $0.2 \pm 0.2$, respectively) (Fig. $4 \mathrm{~A}$ ). On the other hand, transmural infiltration of leukocytes with crypt loss and destruction of epithelial cells were found in colon tissues from vehicletreated mice with TNBS-induced colitis (Fig. 4A, left panel). Treatment with $300 \mathrm{mg} / \mathrm{kg}$ of GGA for 5 days greatly improved inflammatory infiltration and tissue destruction in the colon tissues (Fig.4A, right panel). The histological score was significantly decreased in GGA-treated mice with TNBSinduced colitis compared with that in vehicle-treated mice with TNBS-induced colitis ( $1.8 \pm 0.5$ and $2.8 \pm 0.4$, respectively, $\mathrm{P}<0.05$ vs. vehicle-treated mice) (Fig. 4A).

Effect of GGA on MPO activity in mice with TNBS-induced colitis. To assess the effect of GGA on neutrophil accumulation, we measured the levels of MPO activity in the colon tissue. The levels of MPO activity were low in non-treated mice and ethanol-treated mice $(0.30 \pm 0.18$ and $0.47 \pm 0.23 \mathrm{U} / \mathrm{g}$ protein, respectively) (Fig. 5). Intrarectal administration of TNBS markedly increased the level of MPO activity in the colon tissue of mice treated with the vehicle $(2.40 \pm 0.25 \mathrm{U} / \mathrm{g}$ protein) (Fig. 5). On the other hand, mice treated with $300 \mathrm{mg} /$ $\mathrm{kg}$ of GGA for 5 days showed a remarkable reduction in the level of MPO activity in colon tissue compared with vehicletreated mice $(1.38 \pm 0.07, \mathrm{P}<0.01)$ (Fig. 5).

Effect of GGA on infiltration of CD4-positive $T$ cells in the colons of mice with TNBS-induced colitis. Immunohistochemistry for CD4 was performed to evaluate the effect of GGA on the infiltration of $\mathrm{T}$ cells in mice with TNBSinduced colitis. The number of CD4-positive stained cells was increased in the colon tissue of mice given TNBS and 
A

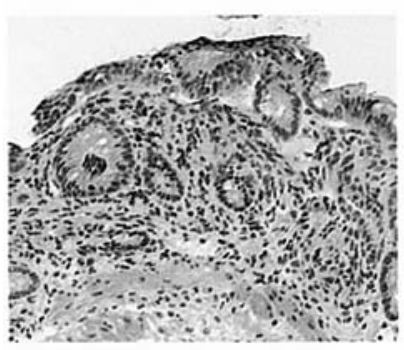

Vehicle

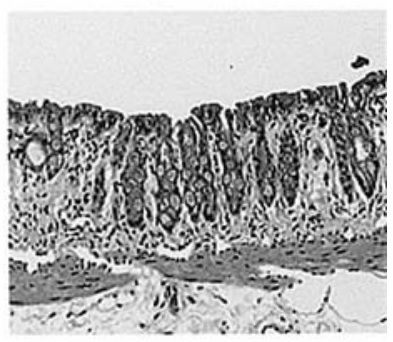

GGA
B

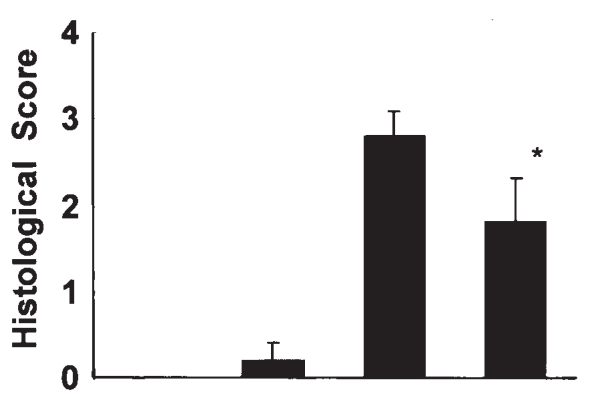

Normal EtOH Vehicle GGA

Figure 4. Effects of GGA on histological findings in the colon tissue of mice with TNBS-induced colitis. Colitis was induced by intrarectal instillation of $0.5 \mathrm{mg}$ of TNBS with $0.1 \mathrm{ml}$ of $50 \%$ ethanol. Mice were repeatedly treated with $300 \mathrm{mg} / \mathrm{kg}$ of GGA every other day up to day 5. (A) The microphotograph of the colon mucosa of mice with TNBS-induced colitis. Left panel, vehicle-treated mice; right panel, $300 \mathrm{mg} / \mathrm{kg}$ of GGA-treated mice. Representative pictures are shown. Similar results were obtained from the samples from other mice (original magnification x200). (B) Histological scores in the colon tissue. Values are expressed as mean \pm SE. $n=5 ;{ }^{*} \mathrm{P}<0.01$ vs. vehicle-treated mice.

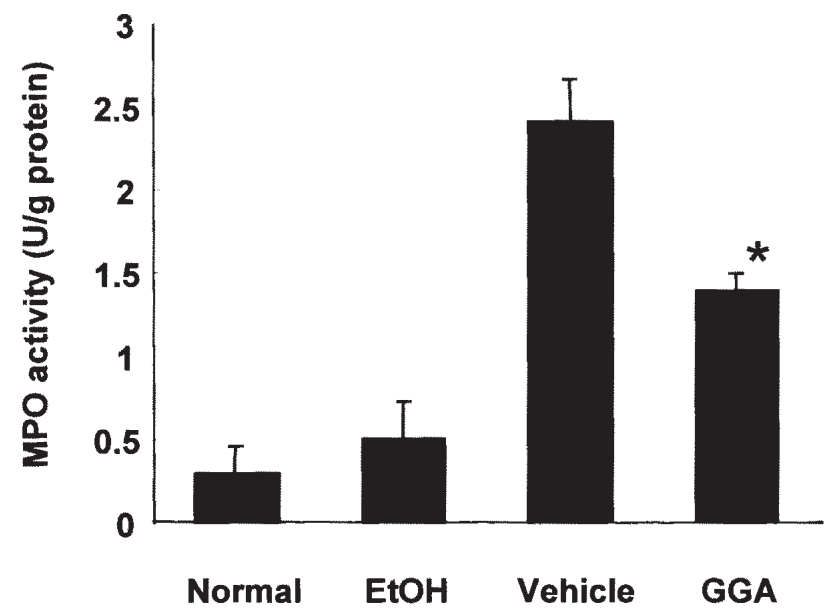

Figure 5. Effect of GGA on MPO activity in mice with TNBS-induced colitis. Colitis was induced by intrarectal instillation of $0.5 \mathrm{mg}$ of TNBS with $0.1 \mathrm{ml}$ of $50 \%$ ethanol. Mice were repeatedly treated with $300 \mathrm{mg} / \mathrm{kg}$ of GGA every other day up to day 5. Normal, non-treated mice; EtOH, ethanol-treated mice; vehicle, vehicle-treated mice with TNBS colitis; GGA, $300 \mathrm{mg} / \mathrm{kg}$ of GGAtreated mice with TNBS colitis. Values are expressed as mean \pm SE. $n=5$; ${ }^{*} \mathrm{P}<0.01$ vs. vehicle-treated mice.

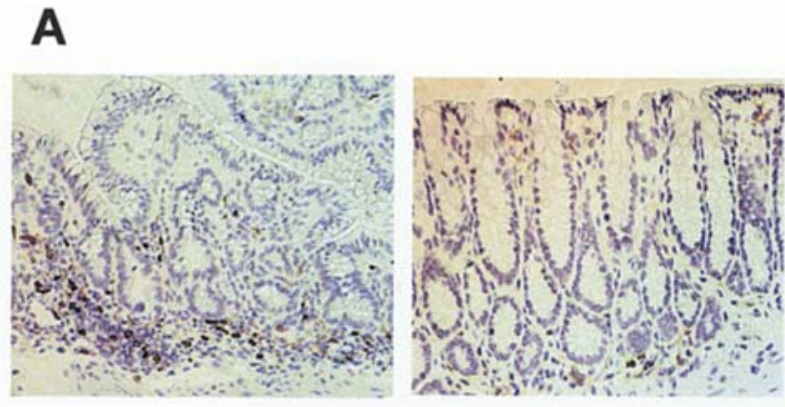

\section{Vehicle GGA}

B

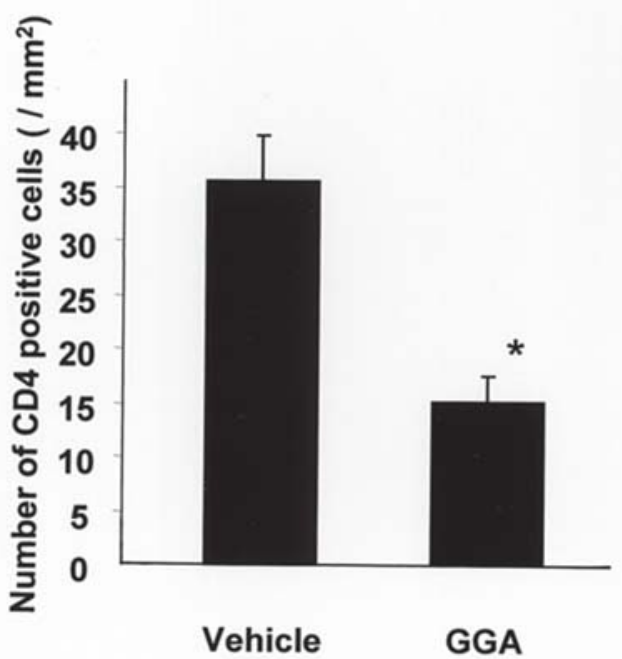

Figure 6. Immunohistochemistry for CD4 in the colon tissue of mice with TNBS-induced colitis. (A) Left panel, the microphotograph in the specimen of colon from vehicle-treated mice with TNBS colitis. Right panel, colon from GGA-treated mice with TNBS-induced colitis (original magnification x200). (B) Number of infiltrating CD4-positive cells. The number of CD4-positive staining cells was counted in the areas of 5 mice with a microscope. Average of cell counts per $\mathrm{mm}^{2}$ was calculated. Values are expressed as mean $\pm \mathrm{SE}$. $\mathrm{n}=5 ;{ }^{*} \mathrm{P}<0.05$ vs. vehicle-treated mice.

\section{HSP70}

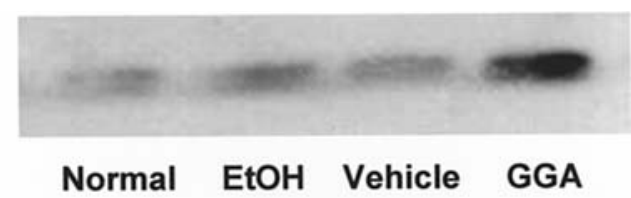

Figure 7. Effect of GGA on induction of HSP70 in the colon tissue of mice. Mice were orally and repeatedly given $300 \mathrm{mg} / \mathrm{kg}$ of GGA or vehicle every other day for 5 days. Colon tissue was removed from mice 5 days postinitial treatment with GGA or vehicle. Western blot analysis for HSP70 in the sample of colon was performed. Normal, non-treated mice; EtOH, ethanol-treated mice; vehicle, vehicle-treated mice with TNBS colitis; GGA, $300 \mathrm{mg} / \mathrm{kg}$ of GGA-treated mice with TNBS colitis. Representative results are shown. Similar results were obtained from three complete experiments.

vehicle $\left(35.6 \pm 4.3 / \mathrm{mm}^{2}\right)$ (Fig. 6A, left panel and B). In mice given TNBS and treated with $300 \mathrm{mg} / \mathrm{kg}$ of GGA for 5 days, the increase in numbers of CD4-positive stained cells in the colon tissue was significantly suppressed $\left(15.2 \pm 2.5 / \mathrm{mm}^{2}\right.$, $\mathrm{P}<0.01$, vs. vehicle-treated mice) (Fig. 6A, right panel and B). 
Effect of GGA on enhancement of HSP70 expression in the colons of mice with TNBS-induced colitis. The expression of HSP70 in the colons of mice with TNBS-induced colitis was determined by Western blot analysis with an antibody specific for HSP70. The expression of HSP70 was weakly detected in colon tissue from non-treated, ethanol-treated and vehicletreated mice on day 5 (Fig. 7). The HSP70 expression level was markedly increased in colon tissue from mice treated with $300 \mathrm{mg} / \mathrm{kg}$ of GGA for 5 days (Fig. 7).

\section{Discussion}

Several murine models of colitis resembling human IBD have been developed to analyze the pathogenesis and the therapeutic effects of drugs. TNBS-induced colitis, which is induced by intrarectal instillation of TNBS, is one of the useful experimental colitis models in mice $(25,28,29)$. This model is characterized by marked transmural infiltration of leukocytes, mainly $\mathrm{T}$ cells. This model of inflammation is considered to be associated with a T-helper 1 cell response and is immunologically similar to Crohn's disease, in which Th1 cells are observed predominantly in the inflammatory lesion $(29,30)$. In this study, we investigated the effect of GGA using a model of colitis induced by TNBS in mice, and we demonstrated that GGA protected mice from TNBS-induced colitis.

GGA has been reported to prevent gastric mucosa from inflammation and ulceration in several experimental models induced by chemicals $(9,10,13,31,32)$. GGA has a protective effect against damage caused by non-steroidal anti-inflammatory drugs (NSAIDs), including indomethacin, in gastric mucosal cells $(10,32)$. In other organs, GGA protects tissues such as the heart and liver from ischemic and surgical damage $(14,15)$. In this study, we demonstrated that GGA clinically and histologically protected mice from TNBS-induced colitis. Our results reveal that GGA potentially plays an antiinflammatory role in the development of TNBS-induced colitis.

In addition to the clinical and histological findings, it was found that the level of MPO activity, as a critical acute inflammatory mediator, in the colon was suppressed in GGAtreated mice with TNBS-induced colitis compared with that in vehicle-treated mice. MPO activity has been shown to be positively correlated with accumulation of neutrophils in local lesions in colons of mice with colitis $(27,33)$. It is thought that treatment with GGA suppresses the increase in neutrophil accumulation in the colons of mice with TNBS-induced colitis. Recently, it has been reported that GGA regulates the expression of interleukin- 8 in the gastric mucosa $(34,35)$. Although the mechanism by which GGA suppressed neutrophil accumulation in colon tissue from mice with TNBS-induced colitis was not clarified in the present study, previous studies and the present study suggest that GGA inhibits neutrophil accumulation via mediating the expressions of chemokines in the colon.

An increase in $\mathrm{T}$ cells infiltrating the colon mucosa is commonly observed in mice with TNBS-induced colitis $(29,30)$. We evaluated the infiltration of T cells into the colon mucosa to investigate the effect of GGA in mice with TNBSinduced colitis. In immunohistochemistry for CD4, treatment with $300 \mathrm{mg} / \mathrm{kg}$ of GGA for 5 days inhibited the increase in number of $\mathrm{T}$ cells infiltrating the colon tissue compared with that in mice treated with the vehicle. There has been no study in which effects of GGA on infiltration of T cells and activation of $\mathrm{T}$ cell-related mediators were investigated. Our results suggest that GGA may, at least partly or indirectly, suppress the activation of $\mathrm{T}$ cells in mice with TNBS-induced colitis.

Recent studies have partially clarified one of the defense mechanisms of GGA in the protection of cells and tissues. GGA markedly and immediately up-regulates the expression of endogenous HSP70, which plays an important role in the protection of cells from stress (13). An in vitro study has shown that up-regulation of HSP70 expression induced by GGA inhibits the process of apoptosis caused by hydrogen peroxide and ethanol in cultured rat hepatocyte (36). Moreover, it has been reported that GGA immediately induces the expression of HSP70 in the rat gastric mucosa (13). These findings suggest that the mechanism of tissue protection by GGA mainly depends on the enhancement of HSP70 expression by GGA. Transgenic overexpression of HSP70 also protects tissues against oxidative and ischemic stresses $(21,22)$. On the other hand, lack of HSP70 severely aggravates cerebral ischemia and infarction in the mouse brain (37). Taken together, the findings suggest that HSP70 plays an essential role in protection against various types of tissue damage. Our previous study also demonstrated a protective effect of GGA on DSS-induced colitis in mice (38). Treatment with GGA significantly improved the clinical and histological findings in the colons of mice with DSS-induced colitis. In addition, administration of GGA enhanced the expression of HSP70 in the colon tissue of mice under normal conditions. Moreover, repeated administration of GGA for 7 days up-regulated the expression of HSP70 in surface epithelial cells in the colon mucosa. In this study, we found that treatment with $300 \mathrm{mg} /$ $\mathrm{kg}$ of GGA for 5 days remarkably up-regulated the expression of HSP70 in the colon tissue of mice given TNBS. Although further study is needed to elucidate the effect and mechanism of induction of HSP70 by GGA in the colon, HSP70 enhanced by GGA may partly contribute to the protection of mice against TNBS-induced colitis.

In conclusion, we demonstrated in this study that GGA protects mice against experimental colitis induced by TNBS. In this model, GGA suppressed the increase of neutrophillic accumulation and strongly enhanced HSP70 expression in the colon. These results provide further evidence that GGA has an anti-inflammatory property in intestinal inflammation and that GGA is a useful drug for the treatment of colitis, including IBD.

\section{Acknowledgements}

We thank Rika Nagashima and Somako Tone for their technical assistance. This work was supported in part by a grant from the Japanese Ministry of Health, Labor and Welfare.

\section{References}

1. Podolsky DK: Inflammatory bowel disease. N Engl J Med 347: 417-429, 2002.

2. Sartor RB: Pathogenesis and immune mechanisms of chronic inflammatory bowel diseases. Am J Gastroenterol 92 (suppl 12): 5S-11S, 1997. 
3. Papadakis KA and Targan SR: Role of cytokines in the pathogenesis of inflammatory bowel disease. Annu Rev Med 51 289-298, 2000.

4. Ohkawara T, Nishihira J, Takeda H, Hige S, Kato M, Sugiyama T, Iwanaga T, Nakamura H, Mizue Y and Asaka M: Amelioration of dextran sulfate sodium-induced colitis by anti-macrophage migration inhibitory factor antibody in mice. Gastroenterology 123: 256-270, 2002 .

5. Van Dullemen HM, van Deventer SJ, Hommes DW, Bijl HA, Jansen J, Tytgat GN and Woody J: Treatment of Crohn's disease with anti-tumor necrosis factor chimeric monoclonal antibody (cA2). Gastroenterology 109: 129-135, 1995.

6. Targan SR, Hanauer SB, van Deventer SJ, Mayer L, Present DH, Braakman T, De Woody KL, Schaible TF and Rutgeerts PJ: A short-term study of chimeric monoclonal antibody cA2 to tumor necrosis factor alpha for Crohn's disease. Crohn's Disease cA2 Study Group. N Engl J Med 337: 1029-1035, 1997.

7. Bickston SJ, Lichtenstein GR, Arseneau KO, Cohen RB and Cominelli F: The relationship between infliximab treatment and lymphoma in Crohn's disease. Gastroenterology 117: 1433-1437, 1999.

8. Keane J, Gershon S, Wise RP, Mirabile-Levens E, Kasznica J, Schwieterman WD, Siegel JN and Braun MM: Tuberculosis associated with infliximab, a tumor necrosis factor alphaneutralizing agent. N Engl J Med 345: 1098-1104, 2001.

9. Terano A, Shiga J, Hiraishi H, Ota S and Sugimoto T: Protective action of tetraprenylacetone against ethanol-induced damage in rat gastric mucosa. Digestion 35: 182-188, 1986

10. Murakami M, Oketani K, Fujisaki H, Wakabayashi T, Ohgo T and Okabe S: Effects of the antiulcer drug geranylgeranylacetone on aspirin-induced gastric ulcers in rats. Jpn J Pharmacol 32: 299-306, 1982.

11. Oketani K, Murakami M, Fujisaki H, Wakabayashi T and Hotta K: Effect of geranylgeranylacetone on aspirin-induced changes in gastric glycoproteins. Jpn J Pharmacol 33: 593-601, 1983 .

12. Fujimono M, Yamanaka T, Bessho M and Igarashi T: Effects of geranylgeranylacetone on gastrointestinal secretion in rats. Eur J Pharmacol 77: 113-118, 1982.

13. Hirakawa T, Rokutan K, Nikawa T and Kishi K: Geranylgeranylacetone induces heat shock proteins in cultured guinea pig gastric mucosal cells and rat gastric mucosa. Gastroenterology 111: 345-357, 1996.

14. Ooie T, Takahashi N, Saikawa T, Nawata T, Arikawa M, Yamanaka K, Hara M, Shimada T and Sakata T: Single oral of geranylgeranylacetone induces heat-shock protein 72 and renders protection against ischemia/reperfusion injury in rat heart. Circulation 104: 1873-1843, 2001.

15. Oda H, Miyake H, Iwata T, Kusumoto K, Rokutan K and Tashiro S: Geranylgeranylacetone suppresses inflammatory responses and improves survival after massive hepatectomy in rats. J Gastrointest Surg 6: 464-472, 2002.

16. Masuda Y, Sumita S, Fujimura N and Namiki A: Geranylgeranylacetone attenuates septic diaphragm dysfunction by induction of heat shock protein 70. Crit Care Med 31: 2585-2591, 2003.

17. Hightower LE: Heat shock, stress proteins, chaperones and proteotoxicity. Cell 66: 191-197, 1991 .

18. Nakamura K, Rokutan K, Marui N, Aoike A and Kawai K: Induction of heat shock proteins and their implication in protection against ethanol-induced damage in cultured guinea pig gastric mucosal cells. Gastroenterology 101: 161-166, 1991.

19. Mestril R, Chi SH, Sayen MR, O'Reilly K and Dillmann WH: Expression of inducible stress protein 70 in rat heart myogenic cells confers protection against stimulated ishemia-induced injury. J Clin Invest 93: 759-767, 1994.

20. Fujimori S, Otaka M, Otani S, Jin M, Okuyama A, Itoh S, Iwabuchi A, Sasahara H, Itoh H, Tashima Y, Komatsu M and Masamune O: Induction of a $72-\mathrm{kDa}$ heat shock protein and cytoprotection against thioacetamide-induced liver injury in rats. Dig Dis Sci 42: 1987-1994, 1997.

21. Marber MS, Mestril R, Chi SH, Sayen MR, Yellon DM and Dillmann WH: Overexpression of the rat inducible $70-\mathrm{kDa}$ heat stress protein in a transgenic mouse increases the resistance of the heart to ischemic injury. J Clin Invest 95: 1446-1456, 1995.
22. Hutter JJ, Mestril R, Tam EK, Sievers RE, Dillmann WH and Wolfe CL: Overexpression of heat shock protein 72 in transgenic mice decreases infarct size in vivo. Circulation 94: 1408-1411, 1996.

23. Ludwig D, Stahl M, Ibrahim ET, Wenzel BE, Drabicki D, Wecke A, Fellermann K and Stange EF: Enhanced intestinal expression of heat shock protein 70 in patients with inflammatory bowel diseases. Dig Dis Sci 44: 1440-1447, 1999.

24. Otani S, Otaka M, Jin M, Okuyama A, Itoh S, Iwabuchi A, Sasahara $\mathrm{H}$, Itoh $\mathrm{H}$, Tashima $\mathrm{Y}$ and Masamune O: Effect of preinduction of heat shock proteins on acetic acid-induced colitis in rats. Dig Dis Sci 42: 833-846, 1997.

25. Dohi T, Fujihashi K, Rennert PD, Iwatani K, Kiyono H and McGhee JR: Hapten-induced colitis is associated with colonic patch hypertrophy and T helper cell 2-type responses. J Exp Med 189: 1169-1180, 1999.

26. Fuss IJ, Marth T, Neurath MF, Pearlstein GR, Jain A and Strober W: Anti-interleukin 12 treatment regulates apoptosis of Th1 T cells in experimental colitis in mice. Gastroenterology 117: 1078-1088, 1999.

27. Ohkawara T, Miyashita K, Nishihira J, Mitsuyama K, Takeda H, Kato M, Kondo N, Yamasaki Y, Sata M, Yoshiki T, Sugiyama T and Asaka M: Transgenic over-expression of macrophage migration inhibitory factor renders mice markedly more susceptible to experimental colitis. Clin Exp Immunol 140: 241-248, 2005.

28. Elson CO, Sartor RB, Tennyson GS and Riddell RH: Experimental model of inflammatory bowel disease. Gastroenterology 109: 1344-1367, 1995.

29. Morris GP, Beck PL, Herridge MS, Depew WT, Szewczuk MR and Wallace JL: Hapten-induced model of chronic inflammation and ulceration in the rat colon. Gastroenterology 96: 795-803, 1989.

30. Pender SL, Chance V, Whiting CV, Buckley M, Edwards M, Pettipher R and MacDonald TT: Systemic administration of the chemokine macrophage inflammatory protein 1 alpha exacerbates inflammatory bowel disease in a mouse model. Gut 54: 1114-1120, 2005

31. Nishida K, Ohta Y and Ishiguro I: Protective and preventive effects of teprenone on gastric mucosal lesions in rats. Eur $\mathbf{J}$ Pharmacol 354: 51-58, 1998

32. Tomisato W, Takahashi N, Komoto C, Rokutan K, Tsuchiya T and Mizushima T: Geranylgeranylacetone protects cultured guinea pig gastric mucosal cells from indomethacin. Dig Dis Sci 45: 1674-1679, 2000

33. Krawisz JE, Sharon P and Stenson WF: Quantitative assay for acute intestinal inflammation based on myeloperoxidase activity. Assessment of inflammation in rat and hamster models. Gastroenterology 87: 1344-1350, 1984.

34. Yoshimura N, Suzuki Y and Saito Y: Suppression of Helicobacter pylori-induced interleukin-8 production in gastric cancer cell lines by an anti-ulcer drug, geranylgeranylacetone. J Gastroenterol Hepatol 17: 1153-1160, 2002.

35. Miyake K, Tsukui T, Shinji Y, Shinoki K, Hiratsuka T, Nishigaki H, Futagami S, Wada K, Gudis K, Iwakiri K, Yamada N and Sakamoto C: Teprenone, but not H2-receptor blocker or sucralfate, suppresses corpus Helicobacter pylori colonization and gastritis in humans: teprenone inhibition of $H$.pylori-induced interleukin-8 in MKN28 gastric epithelial cell lines. Helicobacter 9: 130-137, 2004.

36. Ikeyama S, Kusumoto K, Miyake H, Rokutan K and Tashiro S: A non-toxic heat shock protein 70 inducer, geranylgeranylacetone, suppresses apoptosis of cultrured rat hepatocytes caused by hydrogen peroxide and ethanol. J Hepatol 35: 53-61, 2001

37. Lee SH, Kwon HM, Kim YJ, Lee KM, Kim M and Yoon BW Effects of hsp70.1 gene knockout on the mitochondrial apoptotic pathway after focal cerebral ischemia. Stroke 35: 2195-2199, 2004.

38. Ohkawara T, Nishihira J, Takeda H, Miyashita K, Kato K, Kato M, Sugiyama T and Asaka M: Geranylgeranylacetone protects mice from dextran sulfate sodium-induced colitis. Scand J Gastroenterol 40: 1049-1057, 2005. 